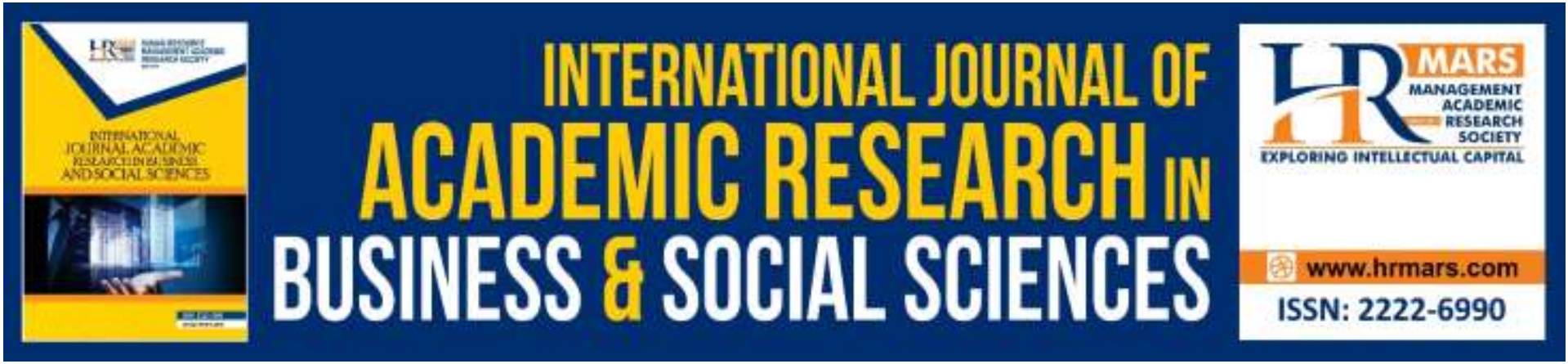

\title{
Talent Management of UiTM Cawangan Negeri Sembilan, Malaysia
}

Mahadir Ladisma @ Awis, Salmiwati Othman, Ainul Fadzilah Binti Harun, and Suhaimi Abd Samad

To Link this Article: http://dx.doi.org/10.6007/IJARBSS/v9-i9/6262

DOI: $10.6007 /$ IJARBSS/v9-i9/6262

Received: 14 June 2019, Revised: 17 July 2019, Accepted: 29 August 2019

Published Online: 06 September 2019

In-Text Citation: (Awis, Othman, Harun, \& Samad, 2019)

To Cite this Article: Awis, M. L. @, Othman, S., Harun, A. F. B., \& Samad, S. A. (2019). Talent Management of UiTM Cawangan Negeri Sembilan, Malaysia. International Journal of Academic Research in Business and Social Sciences, 9(9), 1-17.

\section{Copyright: (C) 2019 The Author(s)}

Published by Human Resource Management Academic Research Society (www.hrmars.com)

This article is published under the Creative Commons Attribution (CC BY 4.0) license. Anyone may reproduce, distribute, translate and create derivative works of this article (for both commercial and non-commercial purposes), subject to full attribution to the original publication and authors. The full terms of this license may be seen at: http://creativecommons.org/licences/by/4.0/legalcode

\section{Vol. 9, No. 9, 2019, Pg. 1 - 17}

Full Terms \& Conditions of access and use can be found at http://hrmars.com/index.php/pages/detail/publication-ethics 


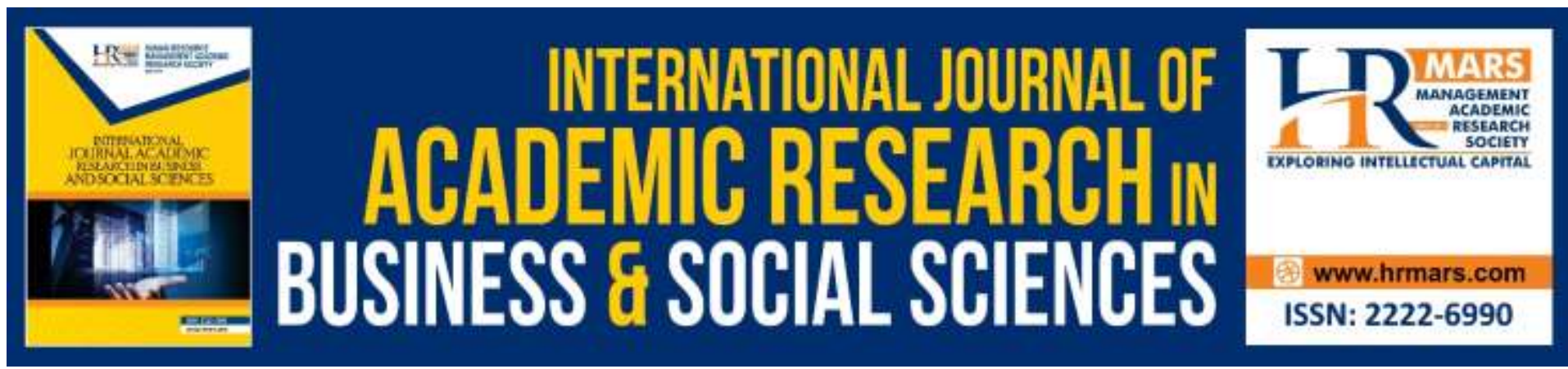

\title{
Talent Management of UiTM Cawangan Negeri Sembilan, Malaysia
}

\author{
Mahadir Ladisma @ Awis ${ }^{1}$, Salmiwati Othman², \\ Ainul Fadzilah Binti Harun ${ }^{3}$, and Suhaimi Abd Samad ${ }^{4}$ \\ 1,2, 4 Faculty of Administrative Science \& Policy Studies, Universiti Teknologi MARA \\ (UiTM), Cawangan Negeri Sembilan, Negeri Sembilan, Malaysia, \\ Email: mahadir.ladisma@gmail.com,salmi618@uitm.edu.my, \\ suhaimi@ns.uitm.edu.my \\ ${ }^{3}$ Universiti Teknologi MARA (UiTM), Cawangan Negeri Sembilan, \\ Kampus Seremban, Negeri Sembilan, Malaysia, \\ Email: ainul@ns.uitm.edu.my
}

\begin{abstract}
The Higher Education Institution just like UiTM Cawangan Negeri Sembilan awares that human capital is one of their greatest treasured resources would have an impressive competitive mechanism. Organizations may choose to focus on the financial capital, information technology, equipment and excellent processes but in the end their personnel and individual staff are the most important asset for their survival. The aim of the research is to investigate the relationship between talent management components (grooming of future leader, career development, skills development and utilization and talent development) toward succession planning in UiTM Cawangan Negeri Sembilan. Furthermore, this research also provides the information regarding the level of succession planning among staff of UiTM Cawangan Negeri Sembilan. Besides, it also identifies the significant influence of the four independent variables towards succession planning. A cross-sectional survey was undertaken in the study to provide data on patterns of talent management and succession planning. Quantitative approach was implemented to gather information and to understand the characteristic across groups or relationships. The findings of this research revealed that, the level of succession planning among UiTM Cawangan Negeri Sembilan staffs is at moderate level and the talent management components has a positive and significant correlation to succession planning. The talent development has been identified to have the most vital effect on succession planning of UiTM Cawangan Negeri Sembilan compared to the others. A few recommendations have also been outlined for the effective succession planning process.
\end{abstract}


Keyword: Talent Management, Grooming of Future Leader, Career Development, Skills Development, Talent Development and Succession Planning

\section{Introduction}

Succession planning is a very popular topic in all types of organizations nowadays and it is an essential survival tool for public university in Malaysia including Universiti Teknologi MARA. By referring to the popular quotes by Mahler (1986) "succession planning, like a relay race, has to do with a passing on responsibility, drop the baton and you lose the race." Another most referred definition of succession planning is: "a process to ensure continued effective performance of an organization, division, department or work group by making provision for the development, replacement and strategic application of key people over time", Rothwell (2010). However, it is ironic that, succession planning has taken place in public university but it is rarely practiced. From the perspective of Davies and Davies (2010) (Davies's model), talent management is defined as a systematic and dynamic process of discovering, developing and sustaining talent. What works depend on the context and the way the organization implements practices.

The purpose of this paper is to study the level of succession planning among UiTM Cawangan Negeri Sembilan staff, to identify the correlation between talent management (grooming of future leaders, career development, skill development and utilization and talent development) among UiTM Cawangan Negeri Sembilan staffs. The last objective is to identify which one of these variables is the most influential in succession planning process.

\section{Background of Study}

Without any doubt, succession planning is definitely important. Due to this, the university's capacity for identifying, selecting, nurturing and developing future leadership can create the distinction between the mandate of the university and failure (Buss, 2001). Selecting a successor for top leader and senior management positions is one of the most vital decisions to be taken by all higher educational institutions.

This study can give us the findings of relationship of succession planning and four (4) main components of talent management towards succession planning in UiTM Cawangan Negeri Sembilan. The respondents were from three (3) main campuses of Negeri Sembilan which are Kuala Pilah, Seremban and Rembau. Total populations of the respondent are 491 staffs from grade 41 to Jusa B. The research was carried out through online survey among the academic and non-academic staffs within 3 weeks. The findings of this study can be used as one of the improvement initiatives in recommended key processes in leadership development of Higher Education Institution (HEls) green book. 


\section{Literature Review: Succession Planning}

Succession planning is now a major concern for a strategic human resource development for every organization. This paradigm is no longer employed solely in profit organization but also for non-for-profit organization in order to find out the potential leadership to business strategy (Wolfred, 2008). This is because the sustainability for the organization to move forward in global competitive is so much relied on the talent pool which to become the highest position in organization. Thus, the succession planning studies are still relevant and important for all sectors. In recent years, few terms have been introduced for succession planning such as talent management, leadership development, leadership pipeline and many more.

However, in discussing this issue, many studies have referred to a comprehensive concept by Rothwell (2010) which has defined succession planning as a mean of identifying critical management positions, starting the levels of project manager and supervisor and extending up to the highest position in the organization. Succession planning also describes management positions to provide maximum flexibility in lateral management moves and to ensure that as individuals achieve greater seniority, their management skills will broaden and become more generalized in relation to total organizational objectives rather than to purely departmental objectives. Other scholars have defined succession planning as the plan an organization employs to fill its most critical leadership and professional positions (Huang, 2001). While Kim (2003) and McDonald (2006) both agreed that it involves process of the ongoing, purposeful, and systematic identification of qualified and appropriate successors to leadership, with a commitment to assessing, developing, and investing in organizational leadership to enhance performance, development, and preparedness.

This area has been discussed widely in many local and international researches like Clunies (2007), Rosse and Levin (2003) on academic and educational organization, Groves (2007) on large corporations like Nokia and General Motors, Chung et al., (2003) on hotel industries, Jarrel and Pewitt (2007) on government sector in the US, and even small medium enterprises by Durst and Wilhelm (2012) and many more. In Malaysia, Abdullah et al., (2009) has come out with research paper on succession planning on institution of higher education in Malaysia, followed by Muslim et al., (2015), Shamsuddin et al., (2012). Other researches like Poorhosseinzadeh and Subramaniam, (2012) have discussed talent management in Multinational Corporations in Malaysia.

Effective succession planning is derived from the talent management, which consists of grooming of future leader, career development, skills development and talent development. These variables have been discussed by many scholars such as Mehdiabadi and Li (2016), Rezaei and Beyerlein (2018), Bradley, (2016), Lagace (2016), Kesler (2002), Sloan et al., (2003), Phillips and Gully (2015), Pruis, (2011), King, (2017), Gritzo et al., (2017), Polychroniou (2009), Annakis et al., (2014), and, Garavan et al., (2011). 


\section{Talent Management}

Mehdiabadi and Li (2016) reviewed Talent Management as the combination of organisations' strategy to utilize the skills of their members in the process of individuals' potential development. It is included in the early process of staff selection and recruitment identification for the right staffs, right skills and competency analysis. Talent management has been defined by Rezaei and Beyerlein (2018) as the systematic identification activities and processes of key positions which contribute to different results to the organizations' sustainable competitive advantage, high potential performance of talent pool development, the development of difference human resources art that suit the talent positions and to make sure the talents give their full commitment to the organizations. Talent management's framework is usually useful to identify and develop the key person in organizations, the critical positions and systems of human resources that are required for university in delivering its strategic missions and objectives. In addition, talent management concept is used at university's hierarchy at all level and certain disciplines (Bradley, 2016).

\section{Grooming of Future Leader}

In organisations, talent gives a key competitive advantage which the managers and appropriate process is tend to select and groom the future leaders as well as training them in the appropriate way (Lagace, 2016). Future's potential in leadership skills can be assessed through the best assessment which is the engagement of the junior or future leaders in senior leadership teams whom can groom them in a consensusoriented where they can be called as calibration committees (Kesler, 2002). At any level, senior top management in organizations together with the Human Resources line need to ensure that they have groomed the right leadership talent, at the right time and importantly in the right place (Sloan et al., 2003).

\section{Career Development}

According to Phillips and Gully (2015) career development which is usually related to succession planning is a continuous system in identification, assessment and development in enhancing the performance of organisation's leadership skills that are involved talent planning, method of assessment, retirement and strategic planning. In the context of career development and career planning, organisation's that offered their talents staffs right and attractive job, positions and project will result to the great learning experience and relevant work experience (Pruis, 2011). The increase in understanding of fairness in Human Resources Management to select talent pool for advanced career development is resulted from the enhancements of talent that practicing clarity, transparency and consistency of job (King, 2017).

\section{Skills Development}

Gritzo, Fusfeld and Carpenter (2017), however have analyzed that leaders can use their organisation's objectives and principles in developing their leadership skills in term of conflict management and overcome the incompetence as well as to develop the future leaders by fostering the innovative culture and environment. The importance of emotional intelligence is also stated in the effectiveness of developing leaders' skill and it may be associated with the type of leadership in organisations 
(Polychroniou, 2009). Talent must be maximized and must be used as a discrete source of employees' competitive advantage as the employees' skills, knowledge and competencies are very important and as vital elements in an organisation (Annakis et al., 2014).

\section{Talent Development}

Garavan, Carbery and Rock (2011) defined talent development as a process that focuses on the selection, planning, strategies of development implementation for the associate talent pool to ensure that the organisation has accurately supply the future and current talent in achieving strategic objectives which produce systematic development process that are parallel with organisational talent management implementation. Inductive and deductive analysis have discovered the generic characteristics of effective Talent Development Environments (TDEs) which are its long term objectives and methods, wide connection messages and support, emphasizing on right development for employees or people, individually selectively and continuously development and development which systematically implemented in integrated and holistic way. Developing and bringing the specific talent management model that can be used in developing talent of employees is one of initiatives in attracting and developing world-class talent with the collaboration between the public and private sectors; (Azman et al., 2016). A study conducted by FMI Corporation in 2017 showed that organisations that practice their talent development model and adopt it into their working culture as well as giving significant commitments in development of professional and learning is resulted to a greater retention.

\section{Theory or Model}

Several theories and models proposed by many scholars in this field were based on different organisational settings which mainly divided into profit and non-profit organisation. Rothwell and Benner Model on succession planning has been widely used in many researches. Most of these models basically explain about the process for effective succession planning. They have explained the step-by-step guidelines or how the human resource and leaders in organization to implement the succession planning.

However, there is no model that fits for all in succession planning. It varies from one industry to another. This study has combined few important variables in talent management studies which resulted in Figure 1 as the conceptual framework of this research.

\section{Conceptual Framework}

This conceptual framework in Figure 1 explains how talent management will influence the facilitation of succession planning process. There are four determinants for succession planning i.e.; grooming of future leader, career development, skills development and talent development. 


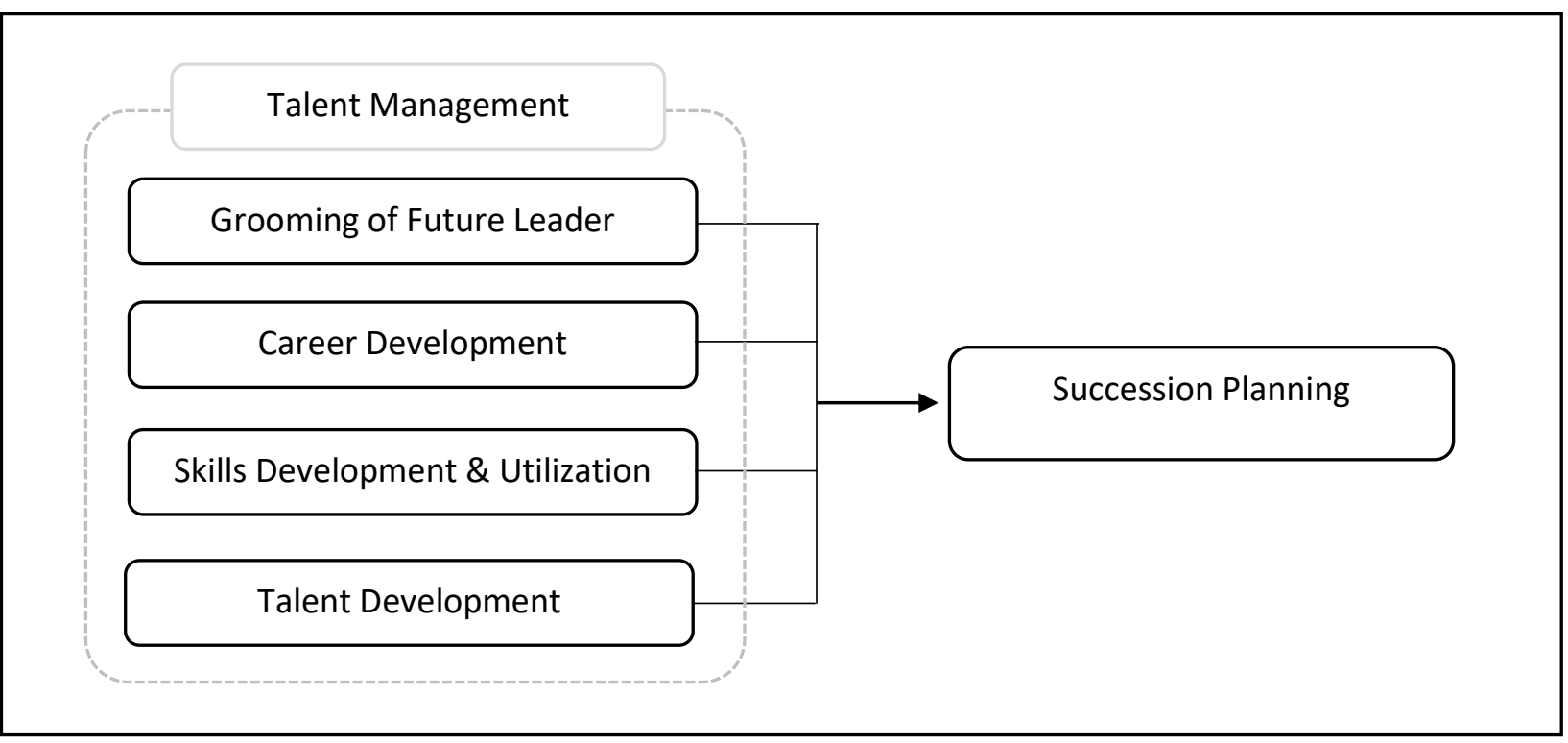

Figure 1: Talent Management of UiTM Cawangan Negeri Sembilan

\section{Methods}

This study seeks to investigate the relationship between the talent management components (grooming of future leader, career, skills and talent development) towards succession planning. The following sub topic further explains the methodological component.

\section{Research Design}

As this study is designed as a quantitative research, the theoretical framework was developed. The theoretical development is later translated into the research hypotheses. The quantitative methodology shared has also complimented the fundamental philosophical with the paradigm positivist. It is based on deductive approach with the testing of hypotheses, the ontology that concerned with reality and characterized with objectivity and generalisability. This study employs a crosssectional survey study where data are gathered just once or in one-shot manner to examine (association/relationship) between the talent management components and succession planning.

\section{Unit of analysis}

The unit of analysis refers to the level of aggregation of the data collected during the subsequence data analysis stage (Sekaran \& Bougie, 2018). The unit of analysis for this study is the individual levels consist of academic (lecturer) and non-academic (administrators) of UiTM Cawangan Negeri Sembilan as at June 2018.

\section{Population, Sample Size and Sampling Design}

The probability sampling is used to select the respondents for this study. The targeted sample size is 246 respondents (Sekaran \& Bougie, 2018:294). The stratified random sampling was applied to select the subgroup of elements within the population. The target sample is among grade 41 and above that involved directly with the succession 
planning of UiTM. Table 1 illustrates the number of sample based on three campuses and two categories of staffs.

TABLE 1:

Population and Sample

\begin{tabular}{clll}
\hline Campus & $\begin{array}{l}\text { Academic } \\
\text { (Lecturer) }\end{array}$ & $\begin{array}{l}\text { Non-academic } \\
\text { (Administrators) }\end{array}$ & Total \\
\hline Kuala Pilah & 131 & 15 & 146 \\
Seremban & 234 & 16 & 250 \\
Rembau & 87 & 8 & 95 \\
\hline Total & $\mathbf{4 5 2}$ & $\mathbf{3 9}$ & $\mathbf{4 9 1}$
\end{tabular}

\section{Data Analysis}

For the purpose of data analysis and hypothesis testing, the data collected had been keyed-in into the Statistical Package for Social Science (SPSS) software. Data is presented by using descriptive statistical, correlational analysis to test the association between variables and multiple regressions analyse is used to identify the most influential variables.

\section{Findings}

Table 2 describes the profile of respondents involved in the study. In total, 156 respondents were selected or took part in this study. There are seven characteristics of respondents highlighted in the study, namely; gender, age, education, grade (academic and non-academic), campus and working experience. The data is presented by using the frequencies and percentage. 
INTERNATIONAL JOURNAL OF ACADEMIC RESEARCH IN BUSINESS AND SOCIAL SCIENCES Vol. 9, No. 9, September, 2019, E-ISSN: 2222-6990 @ 2019 HRMARS

TABLE 2:

Demographic Profile $(N=156)$

\begin{tabular}{|c|c|c|}
\hline Variable & Frequency & Percentage \\
\hline \multicolumn{3}{|l|}{ Gender } \\
\hline Male & 43 & 27.6 \\
\hline Female & 113 & 72.4 \\
\hline \multicolumn{3}{|l|}{ Age } \\
\hline 25 - 30 years old & 24 & 15.4 \\
\hline $31-35$ years old & 67 & 42.9 \\
\hline $36-40$ years old & 26 & 16.7 \\
\hline $41-45$ years old & 16 & 10.3 \\
\hline $46-50$ years old & 8 & 5.1 \\
\hline $51-55$ years old & 12 & 7.7 \\
\hline$>56$ years old & 3 & 1.9 \\
\hline \multicolumn{3}{|l|}{ Education } \\
\hline Diploma & 1 & .6 \\
\hline Degree & 6 & 3.8 \\
\hline Master & 119 & 76.3 \\
\hline PhD & 30 & 19.2 \\
\hline \multicolumn{3}{|l|}{ Grade-Academic } \\
\hline $45 / 46$ & 45 & 28.8 \\
\hline $51 / 52$ & 88 & 56.4 \\
\hline $53 / 54$ & 3 & 1.9 \\
\hline \multicolumn{3}{|l|}{ Grade - Non-Academic } \\
\hline $41-44$ & 16 & 10.3 \\
\hline $45-48$ & 3 & 1.9 \\
\hline $52-54$ & 1 & .6 \\
\hline \multicolumn{3}{|l|}{ Campus } \\
\hline Kuala Pilah & 66 & 42.3 \\
\hline Seremban & 71 & 45.5 \\
\hline Rembau & 19 & 12.2 \\
\hline \multicolumn{3}{|l|}{ Working Experiences } \\
\hline$<3$ years & 8 & 5.1 \\
\hline $3-5$ years & 24 & 15.4 \\
\hline $6-10$ years & 65 & 41.7 \\
\hline $11-15$ years & 33 & 21.2 \\
\hline $16-20$ years & 15 & 9.6 \\
\hline$>20$ years & 11 & 7.1 \\
\hline
\end{tabular}

Table 2 explains the demographic profile of the respondents. Gender shows that 43 respondents (27.6\%) are male and 113 respondents $(72.4 \%)$ are female. Age distribution shows that 67 respondents (42.9\%) are between 31 - 35 years old, followed by group age $36-40$ years old with 26 respondents (16.7\%), 24 respondents (15.4\%) between 25 - 30 years old, 16 respondents (10.3\%) between $41-45$ years 
old, 12 respondents (7.7\%) between 51 - 55 years old and 3 respondents (1.9\%) are more than 56 years old.

Education profile shows that 119 respondents (76.3\%) have a master degree. Followed by 30 respondents (19.2\%) are PhD holder, 6 respondents $(3.8 \%)$ are degree holder and 1 respondent (.6\%) is a diploma holder. Grade position is split into academic (136 respondents) and non-academic (20 respondents). Academy shows that 88 respondents (56.4\%) are grade 51/52. Non-academic shows 16 respondents (10.3\%) in a grade $41-44$, followed by 3 respondents in grade $45-48$ and 1 respondent (.6\%) is grade $51 / 54$.

Respondents are representing three campuses of UiTM Cawangan Negeri Sembilan. Seremban Campus with 71 respondents (45.5\%), followed by Kuala Pilah Campus of 66 respondents (42.3\%) and Rembau Campus with 19 respondents (12.2\%). The respondents' work experience show that 65 respondents (41.7\%) have $6-10$ years of experiences, 33 respondents ( $21.2 \%$ ) shows $11-15$ years experience, 24 respondents (15.4\%) from 3 - 5 years experience, 15 respondents (9.6\%) have $16-20$ years experience, 11 respondents (7.1\%) have more than 20 years experience and 8 respondents $(5.1 \%)$ have less than three-year experience.

The following discussion illustrates the most preferred skills as a leader. There are nine most preferred skills to be a leader in the future. Table 3 explains the nine skills based on a ranked order.

TABLE 3:

Most Preferred Skills as a Leader $(N=156)$

\begin{tabular}{|c|c|c|c|c|c|}
\hline \multicolumn{2}{|l|}{ Skills } & \multirow{2}{*}{ Frequency } & \multirow{2}{*}{$\%$} & \multirow{2}{*}{ Mean } & \multirow{2}{*}{ SD } \\
\hline Number & Most Preferred & & & & \\
\hline \#1 & Decision making & 85 & 54.5 & 3.79 & 3.480 \\
\hline$\# 2$ & Communication skills & 83 & 53.2 & 3.67 & 3.374 \\
\hline \# 3 & Problem solving & 80 & 51.3 & 3.84 & 3.418 \\
\hline \# 5 & Teamwork & 78 & 50.0 & 3.77 & 3.369 \\
\hline \# 6 & Emotional intelligence & 75 & 48.1 & 3.72 & 3.346 \\
\hline \# 7 & Conflict management & 72 & 46.2 & 3.99 & 3.468 \\
\hline \# 8 & Leadership skills & 72 & 46.2 & 3.83 & 3.304 \\
\hline \# 9 & Supervisory & 64 & 41.0 & 3.85 & 3.215 \\
\hline
\end{tabular}

Table 3 shows the nine skills that are expected to be in a future leader. The skills are listed based on the most and to the least preferred. Decision making skill is listed as number one skill by the respondents with 85 (54.5\%). Ranked second is the communication skills with 83 respondents $(53.2 \%)$, followed by problem solving with 80 respondents $(51.3 \%)$, teamwork with 78 respondents $(50 \%)$, emotional intelligence with 75 respondents $(48.1 \%)$, conflict management with 72 respondents $(46.2 \%)$, 
parallel with leadership skills, and supervisory skills with 64 respondents (41\%) is ranked as the least preferred skills.

\section{Analysis}

Research Question 1

What is the level of succession planning among UiTM Cawangan Negeri Sembilan Staffs?

TABLE 4:

Succession Planning Items: Means and Standard Deviations $(N=156)$

\begin{tabular}{|c|c|c|}
\hline Items & Mean & SD \\
\hline Succession Planning & 3.27 & .812 \\
\hline $\begin{array}{l}\text { - In my workplace, top management takes part } \\
\text { on Succession Planning tasks }\end{array}$ & 3.46 & 1.08 \\
\hline $\begin{array}{l}\text { - Top management in my department / unit / } \\
\text { faculty knows well about process of } \\
\text { Succession Planning }\end{array}$ & 3.34 & 1.03 \\
\hline $\begin{array}{l}\text { - Top management in my department / unit / } \\
\text { faculty disseminate adequate information } \\
\text { about Succession Planning }\end{array}$ & 3.04 & 1.04 \\
\hline $\begin{array}{l}\text { - In my department / unit / faculty provide us } \\
\text { the adequate resources in implementing } \\
\text { Succession Planning }\end{array}$ & 3.04 & 1.08 \\
\hline $\begin{array}{l}\text { - Recruitment and placement in my workplace } \\
\text { can affect on the implementation of } \\
\text { Succession Planning } \\
\text { - In my workplace, top management provides }\end{array}$ & 3.71 & 1.01 \\
\hline $\begin{array}{l}\text { clear assessment criteria in Succession } \\
\text { Planning }\end{array}$ & 2.94 & 1.05 \\
\hline
\end{tabular}

Table 4 explains the major component of succession planning. The mean values of succession planning shows that 3.27 mean values with .812 standard deviations. This indicates that there is moderate level of succession planning among staffs. The items "Recruitment and placement in my workplace can affect on the implementation of Succession Planning" shows the highest mean values with 3.71 and 1.01 standard deviations values. The lowest is the item "In my workplace, top management provides clear assessment criteria in Succession Planning" with 2.94 mean values and 1.05 standard deviations.

Research Question 2

What are the association between talent management (grooming of future leaders, career development, skill development and utilization and talent development) among UiTM Cawangan Negeri Sembilan Staff? 
INTERNATIONAL JOURNAL OF ACADEMIC RESEARCH IN BUSINESS AND SOCIAL SCIENCES Vol. 9, No. 9, September, 2019, E-ISSN: 2222-6990 @ 2019 HRMARS

TABLE 5

Correlation, Cronbach Alphas and Convergent and Discriminant $(N=156)$

\begin{tabular}{|c|c|c|c|c|c|c|}
\hline \multicolumn{2}{|c|}{ Variables } & 1 & 2 & 3 & 4 & 5 \\
\hline 1 & Succession Planning & $(.884)$ & & & & \\
\hline 2 & Grooming of Future Leader & $.343^{* *}$ & $(.896)$ & & & \\
\hline 3 & Career Development & $.653^{* *}$ & $.389^{* *}$ & $(.892)$ & & \\
\hline 4 & Skills Development \& Utilization & $.557^{* *}$ & $.584^{* *}$ & $.619^{* *}$ & $(.795)$ & \\
\hline 5 & Talent Development & $.731^{* *}$ & $.286^{* *}$ & $.765^{* *}$ & $.606^{* *}$ & $(.935)$ \\
\hline
\end{tabular}

Table 5 shows the correlation, between Cronbach alphas and convergent and discriminant values among the variables. The data shows that there are positive and significant correlations among the talent management components (grooming of future leader, career development, skills development and utilization and talent development) towards succession planning. The results of the $r$ values is between .343 to 3.765. The most highly correlated with talent management components is the talent development variable with $r=.731$, followed by career development variable with $r=.653$, skills development and utilization variable with $r=.557$ and the lower $r$ value is grooming of future leader with $r=.343$. Table 5 also shows the Cronbach alphas values that indicates the reliability of the items measured. The alphas value is between.795 to .935; talent development (.935), grooming of future leader (.896), career development (.892), succession planning (.884) and skills development and utilization (.795).

Research Question 3

Which is the most influential variable of talent management (grooming of future leaders, career development, skill development and utilization and talent development) and succession planning among UiTM Cawangan Negeri Sembilan Staffs? 
INTERNATIONAL JOURNAL OF ACADEMIC RESEARCH IN BUSINESS AND SOCIAL SCIENCES Vol. 9, No. 9, September, 2019, E-ISSN: 2222-6990 @ 2019 HRMARS

TABLE 6

Multiple Regressions of Talent Management and Succession Planning ( $N=156)$

\begin{tabular}{|c|c|c|c|c|c|}
\hline \multirow[t]{2}{*}{ Model } & \multicolumn{2}{|c|}{$\begin{array}{l}\text { Unstandardized } \\
\text { Coefficient }\end{array}$} & \multirow{2}{*}{$\begin{array}{l}\text { Standardized } \\
\text { Coefficient } \\
\text { Beta } \\
\end{array}$} & \multirow[t]{2}{*}{$\mathrm{t}$} & \multirow[t]{2}{*}{ Sig } \\
\hline & $\mathrm{B}$ & SE & & & \\
\hline Constant & .329 & .276 & & 1.191 & .236 \\
\hline Grooming of Future Leader & .078 & .069 & .075 & 1.129 & .261 \\
\hline Career Development & .150 & .082 & .161 & 1.831 & .069 \\
\hline $\begin{array}{l}\text { Skills Development \& } \\
\text { Utilization }\end{array}$ & .111 & .099 & .092 & 1.130 & .260 \\
\hline Talent Development & .505 & .083 & .531 & 6.100 & .000 \\
\hline F Value & 50.151 & & & & \\
\hline Sig & .000 & & & & \\
\hline Adjusted $\mathrm{R}^{2}$ & .559 & & & & \\
\hline $\mathrm{R}^{2}$ & .571 & & & & \\
\hline
\end{tabular}

a. Predictors: (Constant), Talent Development, Skills Development \& Utilization, Career Development, Grooming of Future Leader

b. Dependent Variable: Succession Planning

Table 6 shows the Model of multiple regressions of talent management and succession planning. The four independent variables in this regression model are grooming of future leader, career development, skills development and utilization and talent development. The value of R2 shows the percentage variance in the dependent variable explained by variation in the independent variables. The value of R2 is .571 shows that $57 \%$ of all independent variables explain the variance in the succession planning. Adjusted R2 penalized the addition of .559 unit of an independent variable (IVs) to the model. The value of $\mathrm{F}$ is 50.151 and it is significant where $\mathrm{p}<.05$.

According to t-test, the result of grooming of future leader, career development, and skills development and utilization towards succession planning found not significant with $p$ values $>.05$ ( $p=.261, \beta=.07 ; p=.06, \beta=.16 ; p=.260, \beta=.09$, respectively). However, talent development is found to be significant at $p<.05$ and $\beta=.53$. Therefore, talent development is positively related with succession planning. Unstandardized beta coefficients are the regression equation value for predicting the dependent variable from independent variable. The regression equation is $Y=.329+$ $.078+.150+.111+.505$. For each one-unit increase in talent development will increase by .505 with succession planning. Standardized beta coefficients predict the dependent variable from the independent variable by expressing in standard deviation form. As talent development increases by one standard deviation, succession planning increases by .531 of a standard deviation. Therefore, based on the Table 6, talent development has the most vital effect on succession planning of UiTM Cawangan Negeri Sembilan. 


\section{Discussion and Conclusion}

Succession planning is done in order to ensure key people to stay and carry out day to day operations with minimum distractions. Succession planning serves for smooth leadership transition. To assure success, the organization needs leadership back and individual development in relevant job categories.

Table 4 illustrates the level of succession planning in UiTM Cawangan Negeri Sembilan which stated that 3.27 mean values with .812 standard deviations indicated that there is a moderate level of succession planning among the staffs. Among the items "recruitment and placement in my workplace can effect on the implementation of succession planning" shows the highest mean values of 3.71 and 1.01 standard deviation values. The findings show that the staffs really concern about the recruitment and placement in their department because it can affect the implementation of succession planning. The lowest item "In my workplace, top management provides clear assessment criteria for Succession Planning" with 2.94 mean values and 1.05 standard deviation. It shows that the top management does not provide a clear assessment tool for their staffs when it comes to succession planning.

The results from Table 5 shows that, there is a significant influence of the four independent variables in this study for grooming of future leader, career development, skills development and utilization and talent management towards succession planning. The test shows that the talent development is the most influencing variable of talent management with $r=.731$. Talent development involves developing leaders via processes such as coaching, feedback, training, mentoring and challenging employees (Evan et al., 2002). Another result, the most preferred skills as a leader stated that the leader must have a good decision making skill (54.5\%) when managing the organization. A great leader understands how to balance emotion with reason and make decision that positively impact themselves, their employees, their customers and stakeholders and their organisations.

The findings in Table 6 show that talent development is positively associated with succession planning and has the most vital effect on succession planning of UiTM Cawangan Negeri Sembilan. Major reasons why succession planning and talent development are important are because of (1) rapid, radical and discontinuous change, (2) increasingly complex challenges, (3) greater leadership responsibility at lower levels and (4) recruitment and retention of the best talent.

Furthermore, the results showed that succession planning in UiTM Negeri Sembilan was moderate and significant toward the talent development process. This study can provide the successful human resource practices by implementing a good talent management to sustain the quality of future talent among staff of UiTM Negeri Sembilan and can contribute the useful guideline for human resource management practices in the present and future Malaysia HEls can be outlined based on the results of this study (Bidayatul et al., 2016). Besides that, this study can be implemented in transformational leadership among the academic leader of HEls because there is the 
perception among the staff that implementation of replacement of academic leader in HEls is not transparent (Zain \& Azman, 2017).

\section{Recommendations}

This paper could not present all the researches in the area, but provides a broad view of talent management in UiTM Cawangan Negeri Sembilan. Based on the conclusions and discussion drawn above, the following recommendations have been made:

i) A succession plan should be customized to the needs, vision and mission of the university. UiTM Cawangan Negeri Sembilan can use the Leadership Development Framework under the University Transformation Programme Orange Book (Titzer, 2017) as a reference.

ii) The most required skill as a leader is the decision making skill which must be customized by the specific training for the leader in UiTM Cawangan Negeri Sembilan. It can be a joint training with ILD and AKEPT.

iii) To ensure a successful implementation of the plan, UiTM Cawangan Negeri Sembilan should give full commitment and full support from the top management and also guided by human resources leaders. This requires clear and proper guidelines and an effective communication about Talent Management among the staffs.

\section{References}

Abdullah, Z., Samah, S. A. A., Jusoff, K., \& Isa, P. M. (2009). Succession Planning in Malaysian Institution of Higher Education. International Education Studies, 2(1): 129 - 132.

Annakis J., Dass M., \& Isa, A. (2014). Exploring Factors that Influence Talent Management Competency of Academics in Malaysian GLC's and NonGovernment Universities, Journal of International Business and Economics, 2 (4): 163-185.

Azman, N., Sirat, M., \& Pang, V. (2016). Managing and Mobilising Talent in Malaysia: Issues, Challenges and Policy Implications for Malaysian Universities, Journal of Higher Education Policy and Management, 38(3): 316-332.

Bano, Y. (2018). A Conceptual Model of Succession Planning for Public Higher Learning Institutions in Malaysia. Journal of Techno Social. 9 (2).

Bidayatul, A. M., Kamil, J. H., Zabeda, A. H., \& Humanika. (2016). Managing Talents in Higher Education Institutions: How Effective the Implementation of Succession Planning? Penerbit UTM Press.

Bradley, P. A. (2016). Talent Management for Universities. Australian's Universities Review, 58 No, 1. 99-113.

Buss, D. (2001). When Managing is not enough: Nine Ways to Develop the Leaders You Need. Workforce 80 (12): 44-48.

Chung-Herrera, B. G., Enz, C. A., \& Lankau, M. J. (2003). A competencies Model: Grooming Future Hospitality Leaders. Cornell Hotel and Restaurant Administration Quarterly, 44(3): 17-25.

Clunies, J. P. (2007). Benchmarking Succession Planning and Executive Development in Higher Education: Is the Academy Ready Now to Employ these Corporate 
Paradigms? Academic Leadership the Online Journal Vol.2 Issue 4, February 13, 2007.

Succession Planning in Malaysian. Retrieved on 15 May 2018 and Available from: https://www.researchgate.net/publication/42386029_Succession_Planning_i n_Malaysian_Institution_of_Higher_Education [accessed Aug 10 2018].

Davies, B., \& Davies, B. J. (2010). Talent Management in Academies. International Journal of Education Management. 24 (5): 418-426.

Durst, S., \& Wilhelm, S. (2012). Knowledge Management and Succession Planning in SMEs. Journal of Knowledge Management. 16(4): 637-649.

Evans, P., Pucik, V., \& Barsoux, J. L. (2002). The Global Challenge: Framework for International Human Resource Management McGraw-Hill. Irwin, New York, NY.

Garavan, T. N., Carbery, R., \& Rock, A., (2012). Mapping Talent Development: Definition, Scope and Architecture, European Journal of Training and Development, 36 (1): 5-24.

Gritzo, L., Fusfeld, A., \& Carpenter, D. (2017). Success Factors in R\&D Leadership: Leadership Skills and Attributes for R\&D Managers. Research Technology Management Arlington, Vol 60 43-51.

Groves, K., S. (2007). "Integrating Leadership Development and Succession Planning Best Practices", Journal of Management Development. 26 (3): 239-260.

Huang, T. C. (2001). Succession Management Systems and Human Resource Outcomes. International Journal of Manpower. 22(8):736-747.

Jarrell, K. M., \& Pewitt, K., C. (2007). Succession Planning in Government: Case Study of a Medium-Sized City. Review of Public Personnel Administration. 27(3): 297309.

Kesler, G. (2002). Why the Leadership Bench Never Gets Deeper: Ten Insights About Executive Talent Development. Managing Partner, Competitive Human Resources Strategies, LLC HR Planning Society Journal. 25 (1): Vol 25 (1) 32-45.

Kim, S. (2003). Linking Employee Assessments to Succession Planning. Public Personnel Management, 32(4): 533-547.

King, K. A. (2017). The Talent Climate: Creating an Organisational Context Supportive of Sustainable Talent Development Through Implementation of a Strong Talent System. Journal of Organizational Effectiveness: People and Performance. 4 (4): 298-314.

Lagace, M. (2016). Grooming Next-Generation Leaders. Australian Universities' Review, Vol. 52, No 1

Martindale R. J. J., Collins D., \& Abraham A. (2006). Effective Talent Development: The Elite Coach Perspective in UK Sport. Journal of Applied Sport Psychology Vol 19 (2) 187-206.

Mahler, W. R. (1986). The Succession Planning Handbook for The Chief Executive. Midland Park, NJ: Mahler Associates Inc.

McDonald, L. R. (2006). Each Business Needs a Thoughtful Succession Plan. The PostStandard. 20 (2): 30-31.

Mehdiabadi, A. H., \& Li, J. (2016). Understanding Talent Development and Implications for Human Resource Development: An Integrative Literature Review Human Resource Development Review. 15 (3): 263 - 294. 
Zain, M. I. M. \& Azman, N. (2017). Transformasi Kepimpinan Institusi Pendidikan Tinggi di Malaysia. Penerbit UPM.

Muslim, S., Haron, S., Hashim, R., \& Hassan, N. (2015). Leadership Development Initiatives to Ensure Succession Planning Effectiveness. Proceedings of the Colloquium on Administrative Science and Technology (pp. 1-10). Springer, Singapore.

Phillips, J. \& Gully, S. M. (2015). Strategic Staffing (3rd Ed). New Jersey: Prentice Hall.

Polychroniou, P. V. (2009). Relationship between Emotional Intelligence and Transformational Leadership of Supervisors. Team Performance Management. 15(7): 343-356.

Poorhosseinzadeh, M., \& Subramaniam, I. D. (2012). Determinants of Successful Talent Management in MNCs in Malaysia. J. Basic. Appl. Sci. Res. 2(12): 1252412533.

Pruis, E., (2011). The Five Key Principles for Talent Development, Industrial and Commercial Training. 43 (4): 206-216.

Rezaei, F. \& Beyerlein, M. (2018). Talent Development: a Systematic Literature Review of Empirical Sstudies. European Journal of Training and Development. 42 (1/2): 75-90.

Rosse, J. G., \& Levin, R. A. (2003). Academic Administrator's Guide to Hiring-Between the Lines. Jossey-Bass: San. Francisco.

Rothwell, W. (2010). Effective Succession Planning: Ensuring Leadership Continuity and Building Talent from Within. Amacom.

Sekaran, U., \& Bougie, R. (2018). Research Methods for Business: A Skill-Building Approach. 6th Edition, Wiley, New York.

Shamsuddin, A., Chee-Ming, C., Wahab, E., \& Kassim, A. S. M. (2012). Leadership Management as an Integral Part of Succession Planning in HEls: A Malaysian Perspective. International Journal of Business and Social Science (3) 3.

Sloan B. E, Hazucha J. F., \& Katwyk P. T. V. (2003). Strategic Management of Global Leadership Talent, in (ed.) Advances in Global Leadership. 3:235-274.

Talent Development in the Construction Industry (2017). FMI Industry Survey, Copyright of FMI Corporation www.fminet.com

Titzer, J. L., Shirey, M. R., \& Hauck, S. (2014). A Nurse Manager Succession Planning Model with Associated Empirical Outcomes. Journal of Nursing Administration. 44(1): 37-46.

Wolfred, T. (2008). Building Leaderful Organizations: Succession Planning for Nonprofits. The Anne E. Casey Foundation: Baltimore, Maryland. 